- FINANSE I PRAWO FINANSOWE.

- Journal of Finance and Financial Law $•$

Wrzesień/September 2019 • vol. 3(23): 9-24

\title{
MANIPULACJE I OSZUSTWA NA RYNKU KAPITAŁOWYM
}

\section{Aleksandra Iczetkin}

Agata Hernik

Wydział Ekonomiczno-Socjologiczny, Uniwersytet Łódzki

\section{Streszczenie}

Manipulacje i oszustwa na rynku kapitałowym są zjawiskiem częstym, choć niedozwolonym przez prawo. Jest wiele kategorii wśród mechanizmów manipulowania rynkiem kapitałowym, jednak konsumenci mają możliwość obrony przed tego rodzaju przestępstwami. Istnieje również wiele możliwości zapobiegania opisanym przestępstwom, zarówno ze strony konsumenta, jak i organów rządowych. Jednak ilość pojawiających się w tym dziele zarzutów pokazuje zarówno znikomą wiedzę społeczeństwa, jak i brak działań ze strony państwa.

Słowa kluczowe: manipulacja, oszustwa, rynek kapitałowy.

JEL Class: G14. 


\section{WPROWADZENIE}

Przestępstwa na rynku kapitałowym stanowią pewien rodzaj oszustw gospodarczych. Z roku na rok instytucje coraz częściej wykorzystują nielegalne działania, takie jak manipulacja instrumentami finansowymi.

Głównym celem niniejszego artykułu jest przedstawienie niektórych przestępstw występujących na rynku kapitałowym oraz wskazanie działań jakie mogą podjąc jego uczestnicy, by uchronić się przed różnego rodzaju oszustwami oraz manipulacjami. Publikacja ta zawiera również badania dotyczące świadomości konsumentów, jak i konkretne przykłady oszustw będących jednymi z największych w historii rynku kapitałowego.

Przyjęto hipotezę, że większości z tych oszustw można uniknąć oraz udowodnić. Analizując poszczególne etapy ich rozwoju, zostały wyszczególnione konkretne działania, które powinny zostać podjęte przez klientów czy też organy państwa, w celu ochrony dóbr inwestora.

\section{MECHANIZMY MANIPULOWANIA RYNKIEM KAPITAŁOWYM}

„Chciwość jest dobra. Chciwość jest słuszna. Chciwość jest skuteczna” - ten znany cytat rozpozna każdy kto choć raz oglądał kultowy film o pracy maklera pod tytułem „Wall Street” w reżyserii Olivera Stone’a. Większość użytkowników rynku finansowego chce osiągnąć jak największe zyski, jednak nie jest to łatwe.

Dążąc do pomnażania wartości oszczędności generuje się popyt na usługi i produkty finansowe o charakterze oszczędnościowo-inwestycyjnym. Jednakże wspomniana wcześniej chciwość w połączeniu z możliwością szybkiego zarobku przyciąga na rynek kapitałowy wielu oszustów. Wizja przyszłego zysku jest w tym wypadku zgubna i prowadzi do zachowań nieetycznych, a często nielegalnych. Czy istnieją z góry określone sposoby manipulacji zarówno produktem, jego ceną, jak i konsumentem? W każdym z tych przypadków odpowiedź brzmi: tak.

\subsection{Giełdowe mechanizmy manipulowania rynkiem kapitałowym}

\subsubsection{Manipulacja informacją na giełdzie}

Zgodnie z definicją Komisji Nadzoru Finansowego (KNF) manipulacja ,jest to zniekształcenie wizerunku emitenta (spółki) poprzez rozpowszechnianie fałszywych informacji na jego temat lub zniekształcenie obrazu instrumentu przez niego wyemitowanego" [Jaroszewicz i Wojciechowska-Mytych 2015: 7]. Art. 39 Ustawy o obrocie instrumentami finansowymi wskazuje jakie czynności 
są uznane za manipulację. Podstawowym elementem manipulacji informacją jest sztuczna zmiana kursu papierów wartościowych. Taka manipulacja rynkiem jest zdefiniowana jako seria transakcji obejmujących kupno lub sprzedaż papierów wartościowych, w celu wykreowania sztucznego wrażenia aktywnego rynku. Niekiedy celem jest podniesienie lub obniżenie notowań rynkowych. Takie działania manipulacyjne na rynku są prowadzone, aby sprowokować jego innych użytkowników do kupna lub sprzedaży określonych papierów wartościowych. Tego typu działania zostały zabronione w USA przez prawo [Sec10(b) Securities Exchange Act, 1934]. Istotą manipulacji jest ingerowanie w swobodę działalności rynków, to z kolei może oznaczać ingerowanie zarówno w czynniki popytowe, jak i podażowe [Dusza 2003: 47-48]. Manipulację kursami akcji można podzielić na dwa zasadnicze obszary. Pierwszy to manipulacja bezpośrednia, która oznacza sterowanie podażą oraz popytem natomiast drugi obszar to manipulacja pośrednia. W tym wypadku elementami głównymi są czynniki mające wpływ na decyzje podejmowane przez inwestorów (manipulowanie informacją). „W przypadku manipulacji, celem sprawców jest osiąganie korzyści majątkowych poprzez wywołanie sztucznej zmiany ceny instrumentów finansowych" [Kądziołka 2016: 4].

W manipulacji informacją na giełdzie można wyróżnić określone schematy postępowania w celu manipulacji. Poniżej przedstawione przykładowe z nich:

- Czysty handel (wash sales). Jest to metoda manipulacji na rynku kapitałowym, polegająca na wywołaniu tendencji wzrostowej cen akcji. Polega ona na wzajemnym odsprzedawaniu między dwiema osobami lub więcej, takiego samego pakietu akcji. Celem tego zabiegu jest ,,podbijanie” jego wartości rynkowej, która zachęca pozostałych inwestorów do ich zakupu. W momencie, gdy cena osiągnie wysoki poziom, członkowie porozumiewają się i odsprzedają wszystkie akcje z odpowiednim nielegalnym zyskiem [Wójcik 2008: 93].

- Pudełkowanie (box job). Polega na początkowym wykupieniu z rynku określonych papierów wartościowych, na które był popyt, w celu obniżenia podaży. Gdy ceny akcji osiągną odpowiedni poziom, posiadacz tych papierów wartościowych odsprzedaje je i przejmuje znaczne korzyści [Wójcik 2008: 91].

- Spółdzielnie (pool). Jest to grupowa manipulacja rynkiem, której głównym celem jest spowodowanie sztucznego wzrostu kursu akcji wybranej spółki. W momencie wyczerpania przez grupę możliwości dalszego wzrostu wybranych papierów wartościowych, następuje ich szybka sprzedaż. W takiej grupie konieczna jest organizacja i dyscyplina, ponieważ gdy chociaż jedna osoba wykona niepożądane działanie, może spowodować straty [Kwieciński 2019: 27].

- Pompuj i porzuć (pump and dump). Polega ona na zawieraniu transakcji kupna, prowadzących do wzrostu ceny danego instrumentu oraz jednocześnie rozpowszechniania pozytywnych (fałszywych) informacji na temat danego emitenta. W chwili, gdy cena wzrośnie do pożądanej wysokości, następuje sprzedaż 
instrumentu finansowego, co powoduje nagły spadek jego ceny [Jaroszewicz i Wojciechowska-Mytych 2015: 11].

- Ustalanie ceny zamknięcia (marking the close). „Polega na kupowaniu lub sprzedawaniu instrumentów finansowych pod koniec notowań w celu spowodowania zmiany ceny zamknięcia danego instrumentu finansowego. (...) gdy inni uczestnicy rynku nie mogą już zareagować na jego zmianę”. Dotyczy to zleceń, które, ze względu na swoją wielkość, mają znaczy wpływ na kształtowanie się podaży, popytu czy też cen danego instrumentu finansowego [Kwieciński 2019: 23].

\subsubsection{Insider trading}

Insider trading to oszustwo polegające na bezpodstawnym ujawnieniu lub wykorzystaniu informacji poufnych i tajemnicy zawodowej w obrocie papierami wartościowymi [Martysz 2013: 85]. Przykładowo, zakup akcji własnej spółki przez członka zarządu, zanim zostaną upublicznione informacje o nadzwyczajnym wyniku firmy, można uznać za tego rodzaju sposób manipulacji. W przypadku insider tradingu, sprawca manipulacji jest z góry na wygranej pozycji względem pozostałych inwestorów, bowiem wykorzystuje on na swoją korzyść posiadaną przez siebie informację, która nie jest ogólnodostępna. Należy jednak pamiętać, że insider trading dotyczy jedynie okresu pomiędzy wejściem danej osoby w posiadanie takiej poufnej informacji aż do momentu jej upublicznienia. Zarówno manipulacja informacją na giełdzie jak i insider trading zostały określone mianem przestępstw w ustawie o obrocie instrumentami finansowymi z 2005 roku [Ustawa z dnia 29 lipca 2005 r..., Dz.U. 2005, nr 183, poz. 1538].

\subsubsection{Sposoby manipulacji na giełdzie wykorzystywane przez maklerów}

- Uprzedzanie (front running). Ta technika często jest stosowana przez osoby pośredniczące w operacjach rynku kapitałowego. Polega ona na dokonaniu przez maklera najpierw jego operacji na określonych papierach wartościowych, a dopiero później operacji klienta, która, jak sądzi makler, ze względu na swoją wielkość spowoduje zmianę notowań rynkowych tego papieru. Najprostszym rozwiązaniem $\mathrm{w}$ takiej sytuacji jest uprzedzenie przez maklera zlecenia swoich klientów, otwierając uprzednio pozycję dla siebie, a dopiero później operacji klienta, po gorszej cenie, tym samym odsprzedając wcześniej zakupione akcje [Dusza 2003: 54-55].

- Bicie piany (churning). Osobami dopuszczającymi się tego oszustwa są maklerzy. Z racji tego, że są oni odpowiedzialni za szereg zadań powiązanych 
z klientem oraz sprawują nadzór nad rachunkiem klienta na podstawie pełnomocnictwa, mają nad nim przewagę, która pozwala im dopuścić się wielu oszustw i manipulacji. Mogą dokonywać zbędnych operacji, jedynie w celu uzyskania prowizji z tytułu obrotu papierami wartościowymi klienta. Cechą charakterystyczną jest sprzeczność interesu klienta a maklera, ponieważ wyższe obroty są związane z wyższą prowizją maklera, ale jednocześnie wyższymi wydatkami klienta oraz ryzykiem jaki może obciążyć jego ewentualny zysk. W takim przypadku, to biuro maklerskie powinno starać się zapobiegać oszustwom uskutecznianym przez jego pracowników, bowiem główny ciężar ochrony interesów klienta spoczywa właśnie na zarządzie biura maklerskiego [Wójcik 2008: 94].

\subsection{Piramidy finansowe}

Kolejną częstą formą przestępstw występującą na rynku są piramidy finansowe. J.W. Wójcik definiuje to zjawisko następująco: „Piramida nie polega na inwestowaniu lecz na przemieszczaniu funduszy pomiędzy uczestnikami. Warunkiem jej powodzenia musi być nieskończona liczba osób, które chcą wziąć udział w tej imprezie" [Wójcik 1998: 93]. Tak więc, w czystej postaci, sprowadza się ona do struktury, w której zyski inwestorów finansowane są z wpłat kolejnych uczestników, którzy znajdują się niżej. Precyzyjnie mówiąc, osiągany zysk zależy od liczby kolejno zwerbowanych przez daną osobę nowych uczestników, a w zasadzie od napływu ich środków finansowych. Nie ma ona racji bytu, bowiem na pewnym etapie liczba uczestników byłaby większa od światowej populacji [Pachucki 2016: 8-9].

Tego rodzaju struktura finansowa jest wzorowana na marketingu wielopoziomowym i często z nim mylona. Piramida na rynku finansowym jest szczególna, ponieważ kolejni inwestorzy przyciągani są wizją dużego zysku poprzez lokowanie środków w instrumenty finansowe czy nieruchomości [Pachucki 2016: 9]. W rzeczywistości zyski mają jedynie charakter ,papierowy”, czyli pokazywane są klientom wyłącznie na wyciągach. Źródłem wypłacanych zysków (które w początkowej fazie są rzeczywiście wypłacane), są środki wprowadzone przez nowych klientów. Wypłacanie ich we wstępnej fazie ma na celu przyciągnięcie coraz to większej liczby interesantów [Pachucki 2016: 10].

Występuje wiele regulacji prawnych, które mają na celu zapobieganiu temu przestępstwu. Jednak twórcy piramid korzystają z pewnych ,niedociągnięć”, które powstały w prawie. Przykładem może być art. 171 prawa bankowego: „Kto bez zezwolenia prowadzi działalność polegającą na gromadzeniu środków pieniężnych innych osób fizycznych, osób prawnych lub jednostek organizacyjnych niemających osobowości prawnej, w celu udzielania kredytów, pożyczek 
pieniężnych lub obciążania ryzykiem tych środków w inny sposób, podlega grzywnie do 10000000 złotych i karze pozbawienia wolności do lat 5" [Ustawa z dnia 29 sierpnia 1997 r..., Dz.U. 1997 nr 140 poz. 939 art. 171] w którym pojęcie gromadzenia jest nieprecyzyjne. Twórcy piramid kreatywnie omijają ten przepis, przykładowo stosując umowę pożyczki lub sprzedaży (np. złota), z odroczoną dostawą (umowa zaliczki) [Masiukiewicz 2014: 47-48].

\section{OBRONA RYNKU KAPITAŁOWEGO PRZED PRZESTĘPSTWAMI I MANIPULACJA}

\subsection{Metody tradycyjne}

Podstawową formą obrony rynku są przepisy prawne. Zasadniczo rozwiązania prawne w większości wysoko rozwiniętych krajów mają charakter kompleksowy i powinny w pełni usuwać z rynku działania sprzeczne z prawem. Dział X Ustawy o obrocie instrumentami finansowymi określa sankcje karne nakładane w przypadku złamania przepisów. Przykładowo art. 138 wspomnianej wyżej ustawy przedstawia: ,Kto dokonuje manipulacji, o której mowa w art. 39 ust. 2 pkt 1-3, pkt $\mathrm{r}$ lit. A lub pkt 5-7, podlega grzywnie do $5000000 \mathrm{zt}$ albo karze pozbawienia wolności od 3 miesięcy do lat 5, albo obu tym karom łącznie" [Ustawa z dnia 29 lipca 2005 r..., Dz.U. 2005, nr 183, poz. 1538 art. 138]. Jednak $\mathrm{w}$ wielu przypadkach przepisy niejednoznacznie określają czyny zabronione, co oszuści chętnie wykorzystują, balansując na granicy prawa. W rzeczywistości nie tak łatwo udowodnić winę w sądzie, choć zdecydowanie szybciej i łatwiej działa w takich przypadkach osąd społeczny, np. przez lokalne media. Dlatego też, w celu ograniczenia możliwości dokonywania manipulacji, wprowadzono tzw. widełki, czyli pewnego rodzaju ograniczenia wahań kursów [Jaroszewicz i Wojciechowska-Mytych 2015: 11]. Istnieją również wyspecjalizowane organy państwowe zajmujące się gromadzeniem dowodów przestępstwa, w Stanach Zjednoczonych mogą to być FBI lub SEC, których zakres działań operacyjnych obejmuje np. obserwację wizualną lub podgląd elektroniczny czy podsłuch. Niekiedy dochodzi nawet do prowadzenia operacji pod przykryciem z wykorzystaniem tajnych agentów policji [www6].

Kolejną linią obrony jest prawidłowe i skuteczne działanie instytucji odpowiedzialnych za poprawne funkcjonowanie rynku, takich jak giełda czy komisja papierów wartościowych. Choć w niektórych krajach, np. w USA komisja papierów wartościowych ma pewne uprawnienia o charakterze policyjnym w celu uskutecznienia ich działania, to jednak - jak pokazują badania - organy nadzorujące pracę rynków giełdowych nie są odpowiednio przystosowane do zwalczania trudnych przypadków oszustw na rynku kapitałowym. Przyczyną takiego zjawiska jest głównie brak odpowiednich środków finansowych. Również po- 
dejście władz do oszustw rynkowych jest kluczowe. W przypadku ich bagatelizowania, opinia publiczna lub sąd, na który władza stara się wywrzeć presję, mogą nie uznać danego czynu za wykroczenie. W efekcie takie podejście może zmniejszyć wiarygodność rynków lub ich segmentów [Dusza 2003: 57-59].

Według M. Grajki następna linia obrony to kodeksy dobrych praktyk przyjmowane $\mathrm{w}$ spółkach lub aprobowanie pewnych rozwiązań o charakterze ogólnym. Takie rozwiązania występują głównie w krajach wysoko rozwiniętych, aczkolwiek ich skuteczność jest nieduża, przez brak realnego zagrożenia od strony karnej. Również instytucje związane z rynkiem kapitałowym, jak banki inwestycyjne czy domy maklerskie, mają duży wpływ na obronę rynku. Poprzez wysokie standardy etyki zawodowej oraz skuteczną kontrolę wewnętrzną mogą zapobiegać szerzeniu się patologicznych zjawisk na rynku kapitałowym. Istnieje zjawisko nazywane „chińskim murem”. Choć wielu deprecjonuje informacje o istnieniu tej nieformalnej umowy, niektórzy wierzą w jej skuteczność, polegającą na umowie nieprzekazywania informacji pomiędzy działami, co miałoby zapobiegać dopuszczaniu się oszustwom [Backet 1991].

Wraz z rozwojem technologii i powszechnej cyfryzacji zwiększa się rola mediów w obronie rynku, pełniąca niekiedy pewnego rodzaju kontrolę. Jednakże opinia ekspertów jest podzielona: czy media chcą jedynie wywołać sensację poprzez nagłośnienie często nieprawdziwych oszustw, czy faktycznie ukazują prawdziwy stan rzeczy i chronią konsumenta ostrzegając go przed np. podejrzanymi inwestycjami.

\subsection{Wykorzystywanie technik nowej generacji w ochronie przed oszustwami}

Z powodu szybkiego rozwoju techniki nowej generacji wśród zabezpieczeń i monitoringów pojawiają się coraz to nowe metody. Jest to świetny sposób obrony rynku i zapobieganiu oszustwom. Przykładowym sposobem zapobiegania zjawisku insider trading jest system alarmowy monitorujący operacje giełdowe. Jeśli któraś z nich odbiega od normy, np. następuje nagły skok cen lub zawarcie dużych transakcji, sygnalizuje on alarmem. Problem pojawia się w momencie gdy do centrali dochodzi zbyt dużo komunikatów ostrzegawczych, tym samym władze giełdy otrzymują zbyt dużo informacji, a ich szybka weryfikacja jest bardzo trudna. $\mathrm{Z}$ tego powodu system ten jest unowocześniony o sztuczną inteligencję. Ten rodzaj zabezpieczenia informuje nie tylko o nietypowym zjawisku, ale o jego wszystkich powiązaniach, zjawiskach dziejących się dookoła transakcji. Przykładowo system może zyskać dane historyczne, aby zweryfikować czy podobne operacje $\mathrm{z}$ danymi klientami oraz $\mathrm{w}$ podobnych okolicznościach miały już miejsce [Dusza 2003: 60-61]. 


\subsection{Etyka inwestorów}

Problematycznym aspektem obrony rynku jest fakt, iż niewielu inwestorów postrzega opisane manipulacje czy oszustwa jako działanie nieetyczne lub przestępstwo, co potwierdzają badania prowadzone podczas afer przy naruszeniach prawnych na rynku kapitałowym ${ }^{1}$. Jest to istotny problem potęgujący brak efektywności w zwalczaniu przestępstw na rynku kapitałowym. Wspomniane badania przeprowadzono w Sydney, Australii oraz USA za pośrednictwem „Business Week" oraz firmy Harris. W obydwu przypadkach ankietowani w ponad $50 \%$ odpowiedzieli, że sami dopuściliby się oszustwa, wykorzystując poufną informację, aby osiągnąć zyski. Daniel Batson wyjaśnia podaną sytuację w pracy naukowej, z której wysnuwa wnioski, iż osoby dopuszczające się oszustwa jednocześnie uważają swoje postępowanie za bardzo dobre, nie widząc w nim nic nieetycznego lub nielegalnego ${ }^{2}$. Etyka inwestorów jest więc niezmiernie istotna oraz oparta o ustawę Prawo o publicznym obrocie papierami wartościowymi, która podkreśla, że maklerzy i doradcy wykonując zawód są zobowiązani działać zgodnie z przepisami prawa i zasadami uczciwego obrotu oraz mieć na uwadze słuszne interesy zleceniodawcy [Ustawa z dnia 21 sierpnia 1997 r..., Dz.U. 1997, nr 118, poz. 754, art. 28].

\subsection{Sposoby obrony przed piramidą finansową}

Należy pamiętać, że instytucje, które oferują różnego rodzaju inwestowanie środków, muszą dokonywać tego na podstawie określonych norm prawnych oraz muszą mieć do tego stosowne pozwolenie Komisji Nadzoru Finansowego (KNF) [Pachucki 2016: 13].

Pierwszym krokiem, jaki powinna uczynić osoba, która chce zainwestować swoje oszczędności, jest sprawdzenie konkretnej organizacji w rejestrze KNF. Podmioty, które działają na zezwolenie KNF, są na bieżąco kontrolowane, co więcej, w przypadku ich upadłości bądź zawieszenia działalności środki klienta zostaną mu wypłacone przez Bankowy Fundusz Gwarancyjny do równowartości 100 tys. euro [Pachucki 2016: 16].

Warto również zwrócić uwagę na „Listę ostrzeżeń publicznych KNF”, gdzie znajdują się podmioty, które podejrzane są o dokonanie przestępstwa na rynku finansowym. W pewnych okolicznościach pozycja z list może być usuwana, jednak możemy umieścić na stronie swój adres e-mail, na który otrzymamy informację w jaki sposób lista była modyfikowana [Pachucki 2016: 15].

\footnotetext{
${ }^{1}$ Wyniki badań podane w: Kaplan [1996].

${ }^{2}$ Opis badania zamieszczonego w artykule Sotin [2002].
} 
Drugą kwestią, na którą klient powinien zwrócić uwagę, jest wysokość oferowanego zysku. Jest to ponad przeciętny procent np. 1\% tygodniowo, gdzie przeciętny zysk na lokacie bankowej wynosi około 3\% w ciągu roku. Dodatkowo, prawdopodobnie, skala ryzyka tej inwestycji będzie znacznie minimalizowana przez osobą oferującą, tzn. nie będzie mu przedstawiony jego faktyczny poziom. Klient powinien wnikliwe pytać o metodę pomnażania kapitału, jak i ryzyko związane z inwestycją oraz nie dać się zwieść „,zawiłą konstrukcją inwestycji”. Co więcej, może uzyskać mylne, lecz prawdziwe informacje, np. o cenie surowca w który pieniądze będą inwestowane, typu złoto, poprzez przedstawienie faktycznego wzrostu jego wartości oraz zapewnienie, że jego cena wzrośnie jeszcze kilkakrotnie [Pachucki 2016: 18-19].

Trzecią kwestią jest gra pozorów, czyli, przykładowo profesjonalnie wyglądająca strona internetowa danego podmiotu, czy też pozytywne komentarze na różnorodnych forach internetowych. Czujność powinna wzbudzić dyskrecja, o którą są proszeni klienci, oraz przedstawienie oferty, która jest skierowana do wąskiego grona odbiorców [Pachucki 2016: 19-20].

\section{PRZYKŁADY OSZUSTW I MANIPULACJI NA RYNKU KAPITAŁOWYM}

\subsection{Afera AMBER GOLD}

Amber Gold była firmą działająca od 2009 roku, która przez pierwszych kilka miesięcy działała pod nazwą Ex Sp. z o. o. Oferowała ona lokaty w złoto i inne kruszce, które miały przynosić wysokie zyski. Firma podawała, że zakupione za te pieniądze złoto jest przechowywane przez Bank Gospodarki Żywnościowej. Jej założycielem był M. Plichta, który był już skazany za oszustwa na tle finansowym. Już w grudniu 2009 roku Komisja Nadzoru Finansowego umieściła Amber Gold na liście ostrzeżeń publicznych oraz zawiadomiła prokuraturę w Gdańsku o możliwości wykonywania przez firmę czynności na rynku bez odpowiedniej licencji [Pachucki 2016: 5-6]. Prokuratura jednak odmówiła wszczęcia śledztwa z powodu braku podstaw do stwierdzenia wystąpienia przestępstwa. Przez kolejne lata klienci zachęceni ponadprzeciętnymi zyskami oraz przyciągani głośną reklamą inwestowali swoje oszczędności, podpisując tzn. umowy składu. W lipcu 2011 roku grupa kapitałowa wykupiła 100\% udziałów spółki Jet Air, wskutek czego Amber Gold stał się głównym udziałowcem powstałych linii lotniczych OLT Express, na co przeznaczyła dużo ponad $200 \mathrm{mln}$ zł. W 2012 roku Agencja Bezpieczeństwa Wewnętrznego zwróciła uwagę na to skąd spółka posiada taką wielkość dostępnych środków [www1]. Powstało pytanie, czy spółka wykorzystuje środki klientów, które miały być przeznaczone na zakup kruszców i finansuje nimi inne przedsięwzięcia. ABW przeprowadziła 
rewizje i wykazała posiadanie przez Amber Gold $57 \mathrm{~kg}$ złota i platyny (o szacowanej wartości $12 \mathrm{mln}$ zł). Jednak założyciel twierdził, że ma $110 \mathrm{~kg}$ złota (o szacowanej wartości $60 \mathrm{mln}$. zł.) oraz warte kolejne kilkadziesiąt milionów złotych nieruchomości. W sierpniu 2012 roku zapadła decyzja o likwidacji spółki, a we wrześniu tego samego roku sąd rejonowy ogłosił jej upadłość. Poszkodowanych działalnością prowadzoną przez Amber Gold zostało ponad 19 tys. osób, które powierzyły swoje środki o łącznej wartości ponad $850 \mathrm{mln}$ zł [Pachucki 2016: 5-6].

Twórcy piramid finansowych starają się ściągnąć do jej uczestnictwa jak największą liczbę klientów, którzy nie są świadomi podejmowanego ryzyka. Warto jest znać sposoby, którymi posługują się jego założyciele, aby nie zostać jego ofiarą.

W przypadku Amber Gold, mogły zawieść organy, które powinny chronić konsumentów przed nieuczciwymi postępowaniami oraz widocznym oszustwem. Skoro, jak pisano wyżej, KNF złożyła wniosek do prokuratury, iż spółka podejmuje działania, do których nie została poprzednio uprawniona, z pewnością był to adekwatny powód do zrewidowania oraz, w chwili nie przedstawienia wymaganych dokumentów, zawieszenia działalności spółki wraz ze zwrotem wierzycielom ich należności.

Jednak potencjalni inwestorzy sami mogli również sprawdzić założyciela firmy, M. Plichtę, który we wcześniejszych latach był skazany za liczne oszustwa, oraz sprawdzić czy firma nie znajduje się na liście ostrzeżeń na stronie $\mathrm{KNF}$, a także zapoznać się ze sprawozdaniem finansowym firmy.

\subsection{Stratton oakmont, czyli wilk z Wall Street}

W latach 80-tych Jordan Belfort pracował w kilku domach maklerskich, między innymi w Investors Centers specjalizującym się w akcjach groszowych. Już rok po dołączeniu do firmy przez Belforta została ona zamknięta przez SEC (United States Securities and Exchange Commission) co stanowi podstawę do myślenia, że przedsiębiorca od początku nabywał wiedzę na temat nielegalnych praktyk na rynku kapitałowym. W 1989 roku Jordan założył firmę Stratton Oakmont. Belfort zatrudnił nowych maklerów i uczył zespół sprawdzonej techniki nazywanej „Kodak pitch”. Zabieg polegał na tym, że zachęcali oni potencjalnych klientów do inwestycji w papiery wartościowe dużej spółki, cieszącej się zaufaniem inwestorów i mającej dobrą płynność finansową, tzw. blue chip. Dopiero kiedy klient „złapał się" na taką przynętę, usłyszał od maklera o kolejnej rzekomo atrakcyjnej inwestycji, niestety w tym przypadku dochodziło do manipulacji, bowiem tak naprawdę proponowane akcje były śmieciowe. Strata inwestora w tym przypadku była z góry przesądzona, a jedynym celem takiej operacji była znacznie 
wyższa prowizja jaką zyskiwał Stratton Oakmont na tego typu akcjach. Choć Jordan twierdził, że pomaga $\mathrm{w}$ ten sposób inwestować w przyszłość Ameryki przeczy temu fakt, iż. swoim klientom proponował, a tak naprawdę wmuszał akcje np. Ventura Enertainment Group, choć strata spółki wynosiła rocznie 455 tysięcy dolarów, przy przychodach plasujących się na poziomie 3 milionów dolarów. Niestety Belford miał o wiele bardziej skomplikowane plany dotyczące oszustw na rynku kapitałowym niż otrzymanie prowizji i opłaty za gwarancje emisji. Dopuścił się on oszustw na jednostkach składających się z warranta subskrypcyjnego oraz jednej akcji. W tym przypadku dochodziło do manipulacji instrumentami finansowymi, a niekiedy także brakiem wiedzy lub zainteresowania ze strony inwestorów. Jak wynika z powyższej analizy Jordan Belfort wraz ze swoimi współpracownikami dopuścili się oszustwa typu „pump and dump”, co dosłownie tłumaczy się jako „pompuj i porzuć”. Maklerzy „pompowali” ceny danych akcji, np. poprzez zakup tych akcji lub rozpowszechnianie pozytywnych, choć niezgodnych z prawdą informacji o danej spółce. Inwestorzy, chętnie kupując polecane przez maklera akcje, nieświadomie przyczyniali się do tworzenia trendu wzrostowego ceny danej akcji [www3]. Gdy cena urosła odpowiednio wysoko, maklerzy „porzucali” akcje, błyskawicznie je sprzedając. Tym samym ich kurs malał, a pozostali inwestorzy na tym tracili. Firma stosowała również ażiotaż, zabieg zbliżony do opisanego schematu „pump and dump” również polegający na przedstawianiu inwestorom fałszywych informacji na temat danej spółki, o wiele pozytywniejszych niż w rzeczywistości. Celem tego zabiegu również była sprzedaż tanio zakupionych akcji po wyższej cenie. W niektórych wypadkach Stratton Oakmont utrzymywał również sztucznie cenę akcji poprzez odmowę lub opóźnienie zleceń sprzedaży akcji. W 1996 roku Stratton Oakmont zamknięto po licznych interwencjach SEC, FBI oraz akcjach dyscyplinarnych NASD (National Association of Securieties Dealers), a 3 lata później Belfort i Porush zostali oskarżeni o oszustwa związane z papierami wartościowym, a także o pranie brudnych pieniędzy [www5]. W Polsce oszustwo „pump and dump" jest szczególnie efektywne w przypadku aktywów finansowych o niskiej płynności, bowiem ich zakup spowoduje znaczny wzrost ich ceny. Niezwykle narażonym rynkiem na to oszustwo może być NewConnect prowadzony poza rynkiem regulowanym, gdzie inwestowanie małych funduszy powoduje znaczne zmiany cen [www4].

\subsection{Piramida Madoffa}

Została ona utworzona przez szanowaną osobę ze swiata biznesu - Bernarda Madoffa. Była to klasyczna piramida finansowa w której środki wpłacane przez nowych uczestników były wypłacane, jako zyski z rzekomych inwestycji. Po- 
czątkowo środki były inwestowane w papiery wartościowe oraz nieruchomości, jednak przez ostatnie 13 lat firma nie inwestowała, a ukazywane klientom zyski były fikcyjne. Oprócz pokazywanych zysków, równie zachęcającym czynnikiem dla klientów, było oferowane roczne zwiększenie aktywów o 8-12\%. Klientami korzystającymi z oferowanych usług były banki, ludzie ze świata biznesu, kultury i polityki, spełniające określone kryteria, a mianowicie, wymagana była rekomendacja oraz minimalna wartość inwestowanych środków wynosiła $10 \mathrm{mln}$ dolarów. Wszystko wydało się w 2008 roku, kiedy to przyszedł kryzys finansowy. Wówczas duża grupa klientów zażądała wypłaty swoich środków, czemu założyciel nie mógł sprostać, ponieważ zyski były wyłącznie na papierze. Pomimo tak wysokich proponowanych zysków, nikt z uczestników nie zorientował się, że może to być oszustwo. Dodatkowo firma była kilkakrotnie sprawdzana przez Komisję Papierów Wartościowych, która nie zauważyła żadnych nieprawidłowości. Straty klientów oszacowano na 65 miliardów dolarów [Piekorz 2017: 4-5].

\subsection{Afera GetBack}

Spółka GatBack S.A. powstała w 2012 r., przedmiotem jej działalności, jak podaje KNF, było „nabywanie pakietów wierzytelności i dochodzenie ich zapłaty na własny rachunek oraz zarządzanie zewnętrznymi portfelami wierzytelności w ramach zarządzania sekurytyzowanymi wierzytelnościami funduszy inwestycyjnych. (...) Wierzytelności nabywane są głównie za środki finansowe pozyskane przez Spółkę z emisji obligacji i wniesione do funduszu poprzez objęcie kolejnych emisji certyfikatów inwestycyjnych." Część pieniędzy z emisji obligacji została pozyskana poprzez ofertę publiczną. Spółka wydała je po otrzymaniu upoważnienia KNF oraz zatwierdzeniu prospektu emisyjnego, w którym to sprawozdania finansowe zostały sprawdzone przez biegłego rewidenta [Komisja Nadzoru Finansowego, 2018].

W pewnym momencie prezes zarządu GetBack S.A. Konrad Kąkolewski ogłosił, że Spółka potrzebuje 1 mld zł kapitału. Wiadomość ta spowodowała, że cena akcji spadła czterokrotnie. Próbowano ratować sytuację poprzez podanie fałszywych informacji, dotyczących prowadzonych negocjacji z PKO BP i Polskim Funduszem Rozwoju o finansowaniu majątkowo-inwestycyjnym w wysokości do 250 mln zł. Spółkę oskarżono o manipulację oraz jednocześnie ukazano znaczne nadużycia przy sprzedaży obligacji. W 2018 roku Giełda Papierów Wartościowych, na wniosek KNF, zawiesiła obrót wszelkimi instrumentami finansowymi wyemitowanym przez GetBack S.A. [www2]. 


\section{4. ŚWIADOMOŚĆ SPOŁECZEŃSTWA NA TEMAT OSZUSTW NA RYNKU KAPITAŁOWYM}

W celu zweryfikowania wiedzy społeczeństwa na temat rynku kapitałowego, podjęto się przeprowadzenia badan wśród 110 losowo wybranych osób zamieszkujących terytorium Polski. Wśród badanych istniało zróżnicowanie pod względem wieku, zawodu oraz wykształcenia. Ankieta składała się z 9 pytań dotyczących wiedzy z zakresu rynku kapitałowego oraz istniejących na nim przestępstw, a także sposobów ochrony konsumenta przed nielegalnymi działaniami. Zadaniem uczestnika było wybranie jego zdaniem najbardziej pasującej odpowiedzi.

Analiza przeprowadzonej ankiety potwierdza, iż świadomość społeczeństwa na temat oszustw na rynku kapitałowym jest niska. Sami ankietowani słabo oceniają swoją wiedzę na ten temat. Może to wynikać między innymi z tego, że większość badanych nie miało osobistego kontaktu z giełdą, to znaczy nigdy nie inwestowali $w$ instrumenty finansowe.

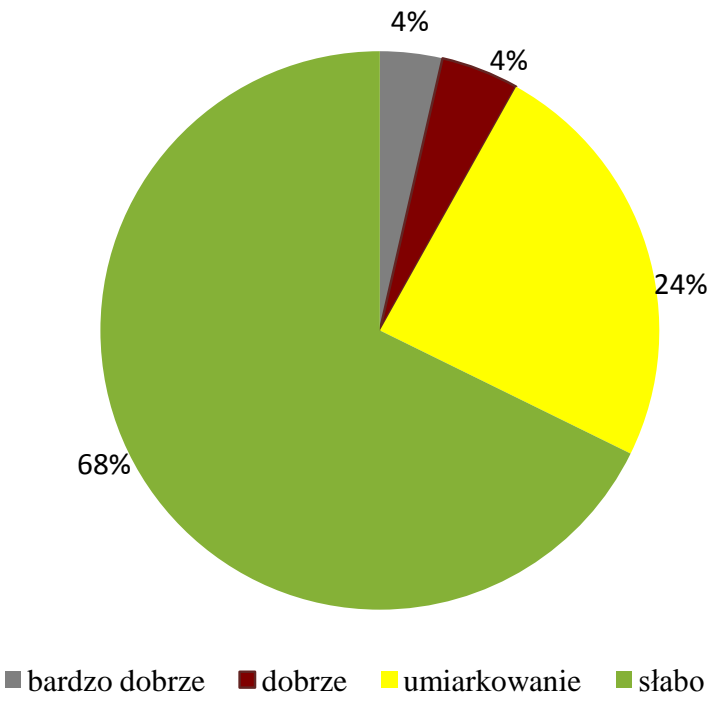

Wykres 1. Ocena własna wiedzy konsumentów na temat oszustw na rynku kapitałowym Źródło: opracowanie własne. 


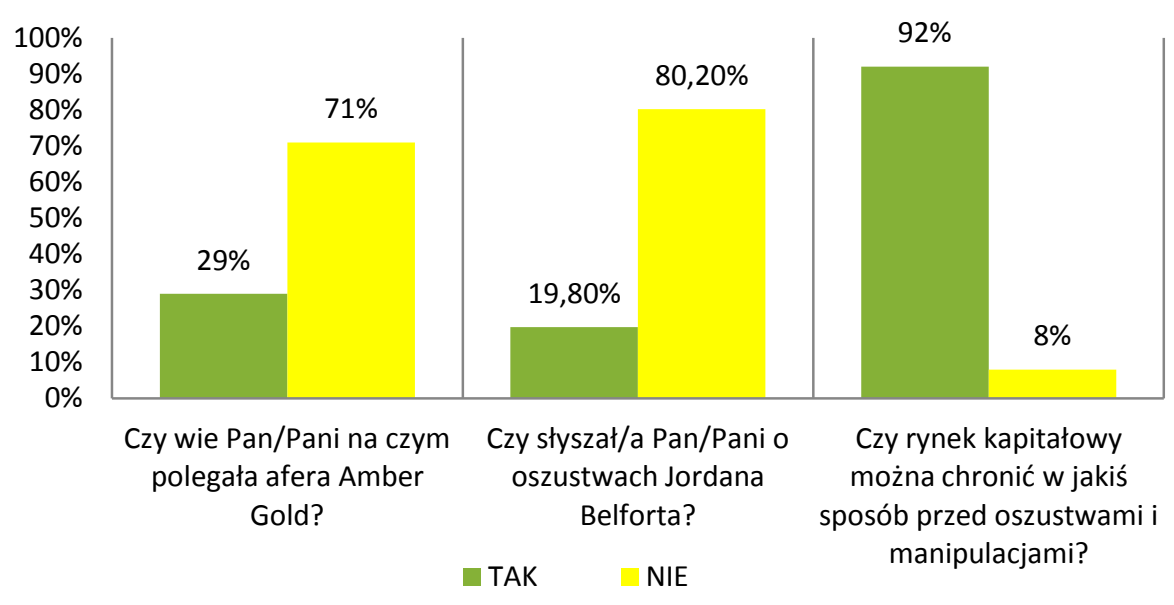

Wykres 2. Odpowedzi konsumentów na zadane pytania

Źródło: opracowanie własne.

Choć wiedza społeczeństwa na temat oszustw i manipulacji na rynku kapitałowym jest niewielka, to jednocześnie istnieje wśród badanych świadomość, że występują metody ochrony rynku, a tym samym jego konsumenta. Jednakże po sprecyzowaniu pytania i odniesieniu się do etyki inwestorów, prawie połowa ankietowanych nie wiedziała na czym ona polega. Taka sama sytuacja wystąpiła po sprecyzowaniu pytania dotyczącego Afery Amber Gold. Pomimo, że 100\% ankietowanych o niej słyszało, to aż $70 \%$ nie wiedziało na czym polegało to przestępstwo.

Na podstawie przeprowadzonej ankiety można więc wyciągnąć wnioski, iż świadomość społeczeństwa na temat oszustw na rynku kapitałowym nie tylko jest niska, ale także maleje wraz z pogłębieniem pytania.

\section{PODSUMOWANIE}

„Chciwość jest dobra i skuteczna”, z takiego założenia wychodzi wielu maklerów, inwestorów oraz przedsiębiorców. Jednak czy chciwość jest opłacalna? To pytanie całkowicie rewiduje pogląd na chciwość i nieposkromioną chęć zysku, bowiem w rzeczywistość daleko posunięta chciwość nie jest opłacalna. Analiza oszustw na rynku kapitałowym dowodzi, że większość z nich da się udowodnić, a klienci mają możliwości uniknięcia ich, zarówno na polu prawnym jak i poprzez pełną świadomość dokonywanych zakupów na rynku. Chociaż system nie 
jest idealny, a przestępstwo nie łatwo jest udowodnić, istnieje wiele czynności, które mogą podjąć zarówno inwestorzy, jak i organy państwa w celu ochrony konsumenta rynku kapitałowego. W artykule zostały ukazane sposoby oszustw i manipulacji na rynku kapitałowym, a także możliwości ochrony konsumenta zarówno na polu materialnym, poprzez, np. systemy alarmowe, ale także psychicznym jak etyka, którą powinni się wykazywać wszyscy uczestnicy rynku, zarówno inwestorzy jak i maklerzy. Również powiększenie wiedzy konsumentów z zakresu prawno-finansowego, a także świadomość mnogości występowania oszustw na rynku kapitałowym mogą doprowadzić do jego ochrony przed nielegalnymi działaniami.

\section{BIBLIOGRAFIA}

Backet M., 1991, Bluff your way in finance, Ravette Books.

Dusza M., 2003, Przestępstwa na rynku kapitałowym. Papierowi Kuglarze, Biblioteka Menadżera i Bankowca, Warszawa.

Jaroszewicz P., Wojciechowska-Mytych K., 2015, Wybrane przestępstwa na rynku finansowym, Komisja Nadzoru Finansowego, Warszawa.

Kaplan Gilbert E., 1996, Beyond the Boesky Affair, Institutional Investor, December.

Kądziołka K., 2016, Wybrane przestepstwa na rynku kapitałowym, https://depot.ceon.pl/bitst ream/handle/123456789/11671/artyku\%c5\%82_K_K\%c4\%85dzio\%c5\%82ka.pdf?sequence $=1$ \&isAllowed $=\mathrm{y}$.

Kwieciński J., 2019, Przestępstwo manipulacji na rynku kapitałowym w świetle ustawy o obrocie instrumentami finansowymi i prawa wspólnotowego, Oficyna Wydawnicza SGH, Warszawa.

Komisja Nadzoru Finansowego, 2018, Komunikat KNF w sprawie spółki GetBack SA, Warszawa.

Martysz Cz., 2013, Prawne i ekonomiczne aspekty karalności insider tradingu, „Studia i Prace Kolegium Zarządzania i Finansów. Zeszyt Naukowy” 124, Szkoła Główna Handlowa w Warszawie, Warszawa.

Masiukiewicz P., 2014, Piramidy a regulacje i nadzór, „Journal of Management and Finance”, vol. 12 , no. $3 / 2$.

Piekorz B., 2017, Największe piramidy finansowe świata, Wrocław.

Pachucki M., 2016, Piramidy i inne oszustwa na rynku finansowy. Poradnik klienta ustug finansowych., Komisja Nadzoru Finansowego, Warszawa.

Sotin W., 2002, Hip, Hip hipokryzja, „Gazeta Wyborcza”, 22 października.

Ustawa z dnia 21 sierpnia 1997 r. Prawo o publicznym obrocie papierami wartościowymi, Dz.U. 1997, nr 118, poz. 754.

Ustawa z dnia 29 sierpnia 1997 r. Prawo Bankowe, Dz.U. 1997, nr 140, poz. 939.

Ustawa z dnia 29 lipca 2005 r. o obrocie instrumentami finansowymi, Dz.U. 2005, nr 183, poz. 1538.

Wójcik J.W., 2008, Oszustwa finansowe. Zagadnienia kryminologiczne i kryminalistyczne., JWW, Warszawa.

Wójcik J. W., 1998, Przestępstwa w biznesie. Zapobieganie, CIM.

[www1] www.aferyfinansowe.pl/afery-w-polsce/amber-gold/.

[www2] www.forbes.pl/biznes/afera-getback-jak-do-niej-doszlo-historia-krok-po-kroku/v98mtdw. 
[www3] www.forbes.p1/life/wydarzenia/jordan-belfort-prawdziwy-wilk-z-wall-street-okiemforbesa/818xye3.

[www4] https://pl.wikipedia.org/wiki/Pump_and_dump.

[www5] https://pl.wikipedia.org/wiki/Stratton_Oakmont.

[www6] http://tradersarea.pl/united-states-securities-and-exchange-commission-sec/.

\title{
FINANCIAL OMBUDSMAN - ANALYSIS OF ACTIVITIES IN THE FIELD
} OF ALTERNATIVE DISPUTES RESOLUTION

\begin{abstract}
Article presents the institution of Financial Ombudsman, who takes actions for benefit of the financial services market's clients. Author sets out with the aim of presenting complaining procedure and analyzing present activities of Financial Ombudsman and future possible changes in Alternative Dispute Resolution sector.
\end{abstract}

Keywords: Financial Ombudsman, financial market participants, complaint procedure, alternative disputes resolution. 